\title{
An Ecommerce Platform and Decision Support for Plants with Comprehensive Information
}

\author{
Anna Fay A. Edulsa, John Benedict L. Bernardo and Precious Mae R. Compo
}

\begin{abstract}
Electronic Commerce site consist of purchasing and selling products which is intended to benefit both gardeners and users. This platform aims to help the local gardeners in selling their plants through online and to provide a more convenient and more reliable way for users to find, view and buy the desired plants that are suitable for their necessity, the customers can also get description and details from the product online. The site also featured an auto suggest engine which the user might use in searching the plants if ever they don't really have an idea on how and what to grow. Problems found that most gardeners had a hard time in selling their plants, in reaching their customer and the insufficient specification on plants and trees that the possible buyer might experience. The researchers conduct a usability test on five (5) end-users and five (5)) IT Professionals a total of ten (10) respondents to gather information on their experience. During the test, the researchers also provided a scenario wherein the respondents act as a buyer who needed to use the auto suggest feature and conduct the whole process of checking out the product. The result has shown that majority of the respondents have agreed that the Auto Suggest really do help them decide which plant to choose and their overall experience was pleasant and intuitive enough that this platform makes it a user-friendly.
\end{abstract}

Keywords-Electronic Commerce, Platform, Auto Suggest

\section{INTRODUCTION}

$\mathrm{P}$ LANTS are essential to the balance of nature and in people's lives. It is a vital part of the world's biological diversity and an essential resource for the planet. People depend upon plants to satisfy such basic human needs. These needs are growing rapidly because of a growing world population, increasing incomes, and urbanization. The capability of plants to satisfy these growing needs is not a new concern. The Reverend Thomas Malthus (1766-1834) argued that people's apathy toward environmental issues would exceed nature's ability to provide subsistence.

In line with this, National Wildlife Federation stated that "Gardeners can play an important role in reducing global

Anna Fay A. Edulsa Department of Information Technology, College of Information Technology and Computing, University of Science and Technology of Southern Philippines, C.M. Recto Avenue, Lapasan, Cagayan de Oro City, 9000 Philippines

John Benedict L. Bernardo, Department of Information Technology, College of Information Technology and Computing, University of Science and Technology of Southern Philippines, C.M. Recto Avenue, Lapasan, Cagayan de Oro City, 9000 Philippines

Precious Mae R. Compo, Department of Information Technology, College of Information Technology and Computing, University of Science and Technology of Southern Philippines, C.M. Recto Avenue, Lapasan, Cagayan de Oro City, 9000 Philippines warming." Taking care of plants and putting it on sale will help combat this serious and potentially devastating environmental problem caused by our negligence. "As gardeners, we are both guardians and stewards of our environment," says Patty Glick, author of the report and Global Warming Specialist for the National Wildlife Federation. However, despite the fact that gardeners can help in the conservation of the environment, there are relevant factors that affects the gardener's profit and revenue. These factors would certainly include, distance traveled to his/her customers, extent of direct competition, and the shortfall of information given by the site itself.

To address that, we have incorporated this platform with an idea to highlight plants. Innovation have made possible for the operations of online platform easy enough to bring you the newest and best choice of plants, we have moved the traditional operations from a shop-based operation to a primarily platform-based one.

Our goal is to build an online community of buyers and sellers of plants and trees, services and information and to help people provide an outlet from their busy lives \& indulge in nature. This is a unique place for nature enthusiasts to browse $\&$ order the best quality of plants online and get them delivered. This would give convenience to a shopper, along with instant satisfaction, for the purchase of a variety of products. Information on how to grow the plants would also be given in a way that to consumers will be educated and encouraged in raising it well so consumers can learn how to nurture and take care of them from a professional. On the other hand, we could also help our local gardeners to advertise their products in a wider range of audience which had been their problem since there are numerous competitors in the market. But among all, we could be able to contribute to raise awareness regarding on the conservation of our environment and the greening of our community that would serve as small steps in saving our environment from further destruction.

All of this work on producing plants in small, populated spaces will have increasing relevance as the world's population continues to urbanize, Sabien O'Hara said: "Small steps you can take like planting plants and trees are hugely important not just for thy own city but for the country and for cities around the world." When all is said, and done, we will be then a step closer in building tomorrow's better environment. 


\section{METHODOLOGY}

Figure 1 shows the System Architecture of a user placing an order using the online platform we created and the flow of transferred bills through payment gateway to the merchant.

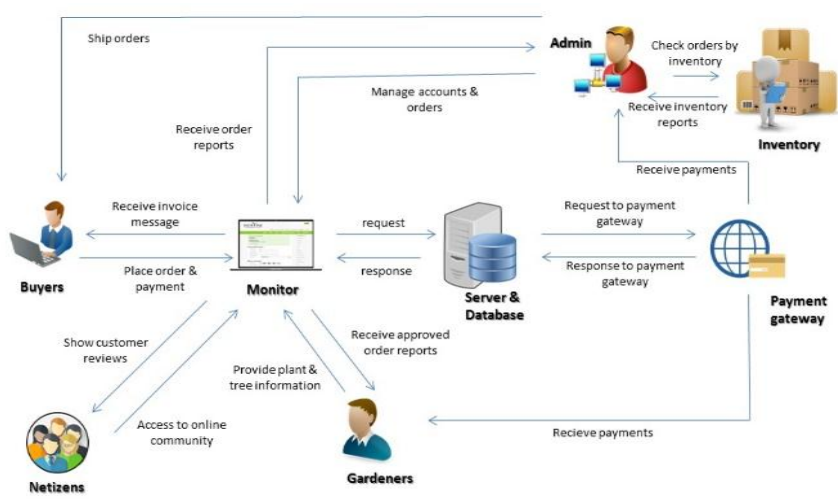

Fig. 1: System Architecture

Figure 2 shows the context diagram is utilized to depict the logical design of the system. The diagram above has four entities namely the Admin, Buyers, Gardeners and Netizens. The user can view a list of plants and trees and its specific information that can be seen on the content of our online platform. They can add, update and delete an order through our system and setup their bills through payment gateway. If transaction has been done the list of orders and payments will be forwarded to the admin and will update and manipulate the data of the system dynamically. Whenever the customer confirms his orders, he will then be redirected to the checkout page which accepts PayPal, credit cards, debit cards and Cash on Delivery as payment gateways.

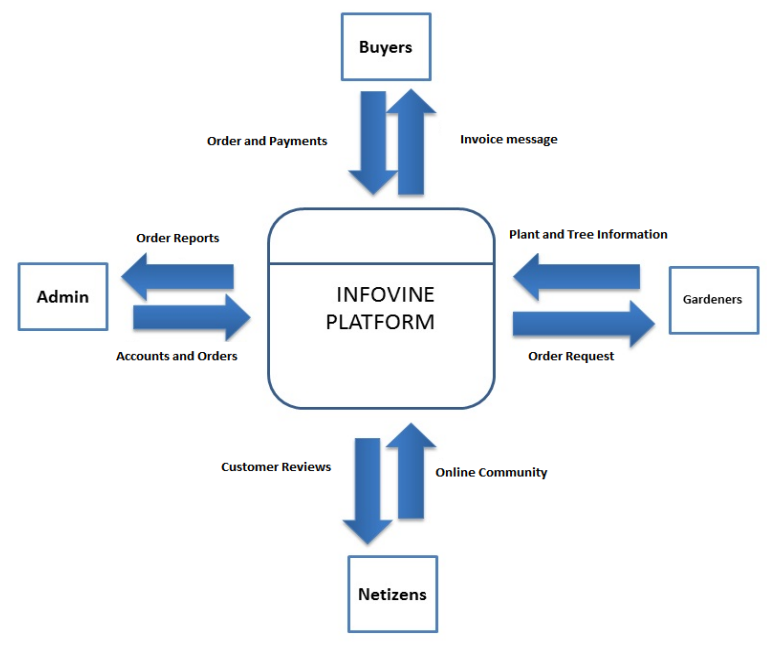

Fig. 2: Context Diagram

Upon viewing the site, the list of variety of the plants that are available is displayed along with its brief information. The user can inquire plants and trees via search engine. The user will then choose their desired plants and proceed to the product details where he/she can review the plants detailed information including the Do's and Don'ts and ways on how to take care of it correctly. He/She can view the ratings of the product that is displayed. And also, can join in the online community where they can share their reviews and even recommendations about the products. The user can directly add the trees or plants to cart and then view your orders in your account and then checkout where you can pay by choosing from our methods of payments (PayPal, Cash on Delivery, etc.

TABLE I:

THE INPUT-PROCESS-OUTPUT APPROACH.

\begin{tabular}{ccc}
\hline \hline Input & Process & Output \\
\hline $\begin{array}{c}\text { Plant's name } \\
\text { And information }\end{array}$ & $\begin{array}{c}\text { Add, edit, } \\
\text { delete, and save } \\
\text { orders to database. }\end{array}$ & $\begin{array}{c}\text { Display } \\
\text { variety of plants } \\
\text { and trees. }\end{array}$ \\
\hline \hline $\begin{array}{c}\text { Users inquiry of } \\
\text { plants and trees via } \\
\text { search } \\
\text { engine }\end{array}$ & $\begin{array}{c}\text { Generating the } \\
\text { customer's request via } \\
\text { search engine. }\end{array}$ & $\begin{array}{c}\text { Detailed } \\
\text { information as a } \\
\text { result. }\end{array}$ \\
\hline \hline $\begin{array}{c}\text { Users inquiry of } \\
\text { plants and trees via } \\
\text { search } \\
\text { engine }\end{array}$ & $\begin{array}{c}\text { Generating the } \\
\text { customer's request via } \\
\text { search engine. }\end{array}$ & $\begin{array}{c}\text { information as a } \\
\text { result. }\end{array}$ \\
\hline \hline
\end{tabular}

\section{TOOLS AND TECHNIQUES}

\section{A. WordPress}

It is a free and open-source content management system (CMS) based on PHP and MySQL. WordPress is installed on a web server, which either is part of an Internet hosting service or is a network host itself.

\section{B. Woo Commerce}

It is a free E-Commerce plugin that allows you to sell anything, beautifully. Built to integrate seamlessly with WordPress, Woo Commerce is the world's favorite ECommerce solution that gives both store owners and developers complete control.

\section{C.SSL (Secure Sockets Layer)}

SSL will be applied after deployment. It creates an encrypted connection between your web server and your visitors' web browser allowing for private information to be transmitted without the problems of eavesdropping, data tampering, or message forgery.

\section{D.MYSQL}

It is a freely available open source Relational Database Management System (RDBMS) that uses Structured Query Language (SQL). SQL is the most popular language for adding, accessing and managing content in a database. It is most noted for its quick processing, proven reliability, ease and flexibility of use.

\section{E. XAMPP}

It is for use only as a development tool, to allow website designers and programmers to test their work on their own 
computers without any access to the Internet. XAMPP also provides support for creating and manipulating databases in MariaDB and SQLite among others.

\section{F. GoDaddy}

Web hosting service which allows individuals and organizations to make their website accessible via the World Wide Web.

\section{G.PayPal}

PayPal is an American company operating a worldwide online payments system that supports online money transfers and serves as an electronic alternative to traditional paper methods like checks and money orders.

\section{EVALUATION Plan}

In order to evaluate the functionality, reliability and security of the system, the end users of our platform such as the selected gardeners and IT professionals are given a chance to operate/try the system by themselves and are asked to evaluate the system by completing a survey questionnaire.

\section{RESULTS AND DISCUSSIONS}

TABLE II: END-USERS RESULT

\begin{tabular}{lllllll}
\hline \hline Evaluation & $\begin{array}{l}\text { Strongly } \\
\text { Agree }\end{array}$ & Agree & Fair & Disagree & $\begin{array}{l}\text { Strongly } \\
\text { Agree }\end{array}$ \\
\hline \hline Functionality & $20 \%$ & $40 \%$ & $20 \%$ & $20 \%$ & $0 \%$ \\
\hline \hline Accessibility & $20 \%$ & $20 \%$ & $40 \%$ & & $20 \%$ & $0 \%$ \\
\hline \hline Reliability & $40 \%$ & $20 \%$ & $20 \%$ & $20 \%$ & $0 \%$ \\
\hline $\begin{array}{l}\text { Overall } \\
\text { Performance }\end{array}$ & $40 \%$ & $20 \%$ & $20 \%$ & $20 \%$ & $0 \%$ \\
\hline
\end{tabular}

This table shows the total percentage of results in the survey questionnaire given to the end users. According to results, $40 \%$ of the respondents strongly agree that the overall functionality of the platform was easy, $40 \%$ also agree, and $20 \%$ fairly thinks that the system functionality needs to be improved. While in the accessibility $60 \%$ of the End-User strongly agreed that their experience was pleasant and the quality of the platform was fine, $20 \%$ also agree, and $20 \%$ thought it was fair enough. It provides a reliable impact to the users of the platform, $40 \%$ Strongly Agree that they can rely on the details that it provide, $20 \%$ actually was pleased and they agree that the site was a huge help in providing an information and would recommend this site to their friend, while $20 \%$ says that they fairly thought they can see themselves using the site intermittently.

TABLE III:

IT PROFESSIONALS RESULT

\begin{tabular}{llllll}
\hline \hline Evaluation & $\begin{array}{l}\text { Strongly } \\
\text { Agree }\end{array}$ & Agree & Fair & Disagree & $\begin{array}{l}\text { Strongly } \\
\text { Agree }\end{array}$ \\
\hline \hline Functionality & $40 \%$ & $40 \%$ & $20 \%$ & $0 \%$ & $0 \%$ \\
\hline \hline Accessibility & $60 \%$ & $20 \%$ & $20 \%$ & $0 \%$ & $0 \%$ \\
\hline \hline Reliability & $60 \%$ & $20 \%$ & $20 \%$ & $0 \%$ & $0 \%$ \\
\hline \hline
\end{tabular}

\begin{tabular}{llllll}
\hline \hline $\begin{array}{l}\text { Overall } \\
\text { Performance }\end{array}$ & $60 \%$ & $20 \%$ & $20 \%$ & $0 \%$ & $0 \%$ \\
\hline
\end{tabular}

This table shows the total percentage results of the survey given to the IT Professional respondents during the system testing. According to the results, only $10 \%$ of the IT Professional had strongly agreed that the general functionality and organization of the site is quite easy, $40 \%$ of them agreed, $20 \%$ fairly thinks that the systems functionality needs to be improved, 20\% thought that the system is not easy to use. While in the Accessibility 20\% Strong Agree that the respondents presume that the site doesn't really has an easy use format, whereas $20 \%$ also agree that their overall experience was pleasant, and $40 \%$ says it was fair enough that platform still needs to be elevate, and 20\% disagree that the site load time was actually reasonable. The IT Professional respondents thought that the platform had been considered to provide a reliable impact, $40 \%$ Strongly Agree that they were pleased with the information that this platform provide, $20 \%$ actually agreed that it was effective in helping them complete the, while $20 \%$ says that they fairly thought they can see themselves using the site in buying products that they need, and $20 \%$ disagree and says that it was not reliable enough.

\section{CONCLUSION}

This e-commerce platform for plants is fully functional and proves itself though the hands of testers and evaluators. Furthermore, the platform gained a positive feedback to all the participants during the tests for the reason that it is a timesaver, accessible, up-to-date and easy to use website based on the findings of this study. The test proves that the platform is a reliable website in regards to gardeners who sell their merchandise online and people who wants to buy plants.

\section{RECOMMENDATIONS}

This study is open to a much better development. The proponents recognize the following as a recommendation to whoever is interested in making the study even better.

The researchers recommend that the e-commerce platform can be improved by adding online chats. With online shopping, buyers interact with sellers via computer networks making transactions that are no longer geographically bound. If online purchases can be done all day and all night long, there is a need to provide 24-hours customer services to solve the majority of pre-sale and after-sale questions. Also, a store finder tab is a must-have option for web stores that have several local or national retailers. Many conservative customers who prefer to check out the actual store itself may visit the website but only to find the nearest shop location or branch. The panel recommends adding a landscape category that would filter and group the plants according to its suitable landscape where it will grow best. They also recommend a detailed form of registration so its information will automatically be inputted on the billing information the moment the buyer will purchase a plant. 


\section{REFERENCES}

[1] Altoveros, N. C. (2007, January). Country report on the state of Plant genetic resources for food and agriculture.

[2] Chatto, B. C. (2016, August). Beth Chatto Gardens [Online] Available: https://www.ornamental-trees.co.uk/about-us-i31

[3] Blaine, T. W. (2014, April). Journal of extension. Profiling Community Gardeners [Online].

Available: http://www.joe.org/joe/2010december/a6.php

[4] Burpee. (n.d.). Garden Advices [Online].

Available: http://www.burpee.com/gardenadvicecenter/about/aboutus/about-us.html

[5] Daily Nation. (2016). Students develop tree calculation app for tree farmers [Online].

Available:http://www.nation.co.ke/business/seedsofgold/Studentsdevelop-tree-calculation-app-for-tree-farmer/2301238/3181840//3apaa1z/-/index.html

[6] Den Garden. (n.d.). Smartphone apps for plant lovers [Online]. Available: https://dengarden.com/gardening/Free-Smartphone-Apps-forPlant-Lovers

[7] Feehling, E. (n.d.). Plants information guide [Online]. Available: http://info.plantsmap.com/

[8] flowers, 1. (n.d.). Floral shops in the market [Online]. Available: https://www.1800flowers.com

[9] Inhabitant. (n.d.). Environmental preservation [Online]. Available: http://inhabitat.com/7biggest-threats-to-the-environmentwhy-we-still-need-earth-day/

[10] Larson, D. W. (2001). Encyclopedia. Retrieved from Economic Importance of Plants [Online]. Available: http://www.encyclopedia.com/doc/1G2-3408000121.html

[11] McGroarty, M. (n.d.). Mikes Backyard Nursery [Online]. Available: http://mikesbackyardnursery.com/2012/10/starting-a-plantbusiness/

[12] McKee, S. (2014, July 18). Business management [Online]. Available:http://www.greenhousegrower.com/business management/should-you-be-selling-plants-and-products-online/

[13] Monrovia. (n.d.). About Monrovia [Online]. Available: http://www.monrovia.com/about-us/

[14] O'Hara, S. (2015). Botanic Gardens Conservation International 'ROOTS publication.

[15] Plant Services Magazine. (2009). Proflora bulletin [Online]. Available: http://www.plantservices.com

[16] Quick, B. (2013). Public awareness on environmental problems [Online]. Available: http://classroom.synonym.com/ways-increasepublic-awareness-environmental-problems-2590.html

[17] Shahrzad Shahriari, M. S. (2015, April). E-Commerce And Its Impacts On Global Trend And Market [Online]. Available: http://granthaalayah.com/Articles/Vol3Iss4/03_IJRG15_A04_63.pdf

[18] Wayside Gardens. (n.d.). About Wayside Gardens [Online] Available: http://www.waysidegardens.com/about-us/a/300/

[19] Wells, N. M. (2006). National Wildlife Federation. Gardeners Can Play An Important Role In Reducing Global Warming. 